\title{
Race, Residence, and Violent Crime: A Structure of Inequality
}

\author{
Ruth D. Peterson \& Lauren J. Krivo*
}

\section{INTRODUCTION}

There is a great deal of variation in levels of violent crime across communities of different colors in urban neighborhoods throughout the United States. This variation is seen in rates of violence that are much higher in predominantly minority neighborhoods, especially those comprised of blacks, compared to predominantly white neighborhoods. ${ }^{1}$ This Article addresses the question of how to account for stark differences in criminal violence across communities of varying colors. We draw on arguments set forth by race and ethnic scholars in the social sciences who contend that the social organization of U.S. society is structured to produce and reinforce a racial order where whites are privileged over other groups. ${ }^{2}$ This racialized order is evident in

Distinguished Professor of Social and Behavioral Sciences, Professor of Sociology and Director of the Criminal Justice Research Center, Ohio State University, and Professor of Sociology and Associate Director of the Criminal Justice Research Center, Ohio State University, respectively. We are grateful to Derrick Darby and Kelly Foos for the invitation to participate in the Kansas Law Review 2008 Symposium on "Law, Reparations, and Racial Disparities." We also thank Jelani Jefferson Exum and other symposium participants for insightful comments and suggestions that we received during the symposium. This research was supported by a grant from the National Science Foundation (SES-0080091).

1. See, e.g., Robert D. Crutchfield et al., Race, Labor Markets, and Neighborhood Violence, in The Many Colors of Crime: Inequalities of RaCe, Ethnicity, AND CRime IN AMERICA 199, 199 (Ruth D. Peterson et al. eds., 2006) (suggesting neighborhoods with high concentrations of minorities have higher rates of violence); Robert J. Sampson \& William Julius Wilson, Toward a Theory of Race, Crime, and Urban Inequality, in CRIME AND INEQUALITY 37, 37 (John Hagan \& Ruth D. Peterson eds., 1995); Lauren J. Krivo \& Ruth D. Peterson, Extremely Disadvantaged Neighborhoods and Urban Crime, 75 SOC. FORCES 619, 620 (1996) (explaining racial differences in crime in poor neighborhoods); Thomas L. McNulty, Assessing the Race-Violence Relationship at the Macro Level: The Assumption of Racial Invariance and the Problem of Restricted Distributions, 39 CRIMINOLOGY 467, 467-68 (2001) (explaining racial differences in rates of violence).

2. See, e.g., Lawrence D. Bobo, Inequalities That Endure? Racial Ideology, American Politics, and the Peculiar Role of the Social Sciences, in THE CHANGING TERRAIN OF RACE AND ETHNICITY 13, 26-31 (Maria Krysan \& Amanda E. Lewis eds., 2004) ("Laissez-faire racism involves ... resistance to meaningful policy efforts to ameliorate U.S. racist social conditions and institutions."); EDUARDO BONILLA-SILVA, RACISM WithOUT RACISTS: COLOR-BLIND RACISM AND THE PeRsistence of RACIAL INEQUALITY IN THE United STATES 8-11 (2d ed. 2006) [hereinafter Racism Without Racists]; Eduardo Bonilla-Silva, White Supremacy and Racism in the 
contemporary society but has roots in historical patterns that are connected with slavery and Jim Crow. From this point of view, the historically rooted systemic racial structure is reflected in inequality in a variety of arenas, one of which is neighborhood violence.

Here, we seek to explore how racialized structural patterns undergird the highly inequitable rates of criminal violence evident across communities of distinct colors - a pattern that reflects the striking white privilege of being able to live in dramatically safer neighborhoods than all other groups of color. Taking this perspective shows how differential patterns of violence across ethnoracial groups are products of structural relations of society rather than stemming from individual differences in propensities to engage in violent behavior. We, therefore, expose the ways in which historically-based structural relations must be front and center in understanding contemporary ethnoracial inequality in the United States.

Our discussion proceeds in four parts. First, we explain in greater detail our conceptual framework for understanding inequality in rates of violence. This is a two-part discussion in which we focus on (1) the theory of a racialized social structure and (2) why violence stems from such a structural organization. Second, we describe the nature of the data and methods employed to examine the proposed relationships. Importantly, we use unique data on neighborhood criminal violence that allows for exploration of patterns for a representative set of large cities throughout the United States. Previous research on this topic has been limited to analyses of areas within a single or a few cities. Third, we present descriptive findings regarding community differences in neighborhood social conditions and violence. These results make clear the extent to which ethnoracial groups live in divergent social worlds. This is followed by multivariate findings on the net contributions of particular neighborhood social conditions to differences in violent crime across neighborhoods of distinct colors. Finally, we draw conclusions

Post-Civil Rights ERA 12 (2001) [hereinafter Bonilla-Silva, White SuPremacy]; Manning Marable, The Political and Theoretical Contexts of the Changing Racial Terrain, in THE Changing TERRAIN OF RACE AND ETHNICITY, supra, at 224, 225-33 ("The disproportionate wealth that most white Americans enjoy today was first constructed from centuries of unpaid black labor."); MichaEl OMI \& HOWARD WinANT, RACial Formation IN THE UNited STATES: From tHE 1960S TO THE 1990S 79 (2d ed. 1994) ("The major institutions and social relationships of U.S. society ... have been structured from the beginning by the racial order."). See generally JOE R. FEAGIN, RACIST AMERICA: ROOTS, CURRENT REALITIES, AND FutURE REPARATIONS 137-74 (2000) ("White prerogatives stem from the fact that society has, from the beginning, been structured in terms of white gains and white-group interests."). 
regarding the implications of a racialized structure for violent crime, and for approaches to reducing or eradicating ethnoracial inequality in patterns of violence.

\section{RACIALLY STRUCTURED SOCIETY}

A central idea articulated by many race scholars in the social sciences and legal literature is that race is a central organizing principle within and across societies. ${ }^{3}$ In the United States, this means that society is patterned in such a way as to reproduce and sustain the privileges of whites over other groups, and to position blacks at the bottom of the social hierarchy. ${ }^{4}$ The social positions of other ethnoracial groups are often considered to fall between these two extremes. Recently, BonillaSilva and Glover have proposed that the racial order is tripartite, with whites at the top of the hierarchy, blacks at the bottom, and a set of others including light-skinned Latinos, Asian Americans, Middle Eastern Americans, and multiracial individuals structurally in the middle as honorary whites. ${ }^{5}$ According to this organization, blacks include a broad set of very dark-skinned groups. ${ }^{6}$ This perspective suggests growing complexity in the nature of racial stratification in the United States. Although there are on-going discussions and evaluations of the specific merits of Bonilla-Silva and Glover's tri-racial perspective, scholars appear to agree that the racial order in the United States is heavily defined by the extremes of white privilege and black oppression. ${ }^{7}$

Whatever the specific positions of different groups, all of the institutions that comprise a racialized social system are organized to maintain a hierarchy of white privilege and minority oppression. ${ }^{8}$ Schools, the labor market, politics, and the health care system provide opportunities that are systematically differentiated across populations of color. ${ }^{9}$ Specifically, the dominant white population has greater access to

3. In this paper, we draw on a structural race approach discussed by sociologists and other social scientists. For an overview of critical race theory as discussed among legal scholars, see generally Richard Delgado \& Jean Stefancic, Critical Race Theory: An Introduction (2001).

4. See sources cited supra note 2.

5. Eduardo Bonilla-Silva \& Karen S. Glover, "We Are All Americans": The Latin Americanization of Race Relations in the United States, in THE CHANGING TERRAIN OF RACE AND ETHNICITY, supra note 2, at 150-51.

6. Id.

7. See generally EduARdo Bonilla-Silva, 5 RACE AND SOCIETY (2002) (where a number of scholars assess the merits of Bonilla-Silva's tri-racial perspective with responses by Bonilla-Silva).

8. See generally Bonilla-Silva, White SuPREMACY, supra note 2, at 94-103.

9. See generally 1-2 AmericA BECOMING: RACIAL TRENDS AND Their CONSEQUENCES (Neil 
high quality institutional resources. ${ }^{10}$ This includes disproportionate opportunities to attend the best schools, obtain prestigious jobs, gain political representation, and utilize the highest quality doctors and hospitals. ${ }^{11}$ As a result, whites typically accrue the greatest rewards from institutional resources, e.g., higher income, more education, better health, and greater wealth. ${ }^{12}$ Superior opportunities and rewards take on a life of their own in furthering the privileges of whites. That is, whites' accumulated advantages facilitate their ability to maintain superior positioning throughout society. For example, access to communities with the best public elementary schools and high schools not only improves access to college, along with all of the opportunities flowing from high educational attainment, but also increases home values, and hence the wealth of residents. ${ }^{13}$ Wealth can, in turn, help finance college and other investments that facilitate continued returns. ${ }^{14}$ In contrast, non-whites, and particularly blacks, experience significantly lower life chances in institutional arenas. This includes a greater likelihood of poor quality education, low prestige jobs with associated low income, and residence in heavily impoverished communities with low home values and weak potential to accumulate wealth. ${ }^{15}$

The above arguments do not deny variation in achievement within racial groups; nor do they call into question evidence of upward mobility and growth in the middle class among blacks and other groups of color. ${ }^{16}$ Indeed, after the civil rights movement and related legislation, the number of middle class blacks grew at least into the 1970s. ${ }^{17}$ However,

J. Smelser et al. eds., 2001) (compiling data on racial disparity trends in health care, education, justice, and income).

10. See generally id.

11. See generally id.

12. See generally id. (concluding that the trends in racialized social systems create benefits to the controlling group).

13. See, e.g., Melvin L. Oliver \& Thomas M. Shapiro, Black Wealth/White Wealth: A New Perspective on Racial IneQuality 11-13, 84-87 (10th ed. 2006). See generally Thomas M. Shapiro, The Hidden Cost of Being African American: How Wealth Perpetuates INEQUALITY 2-18, 155-82 (2004).

14. See, e.g., Dalton Conley, Being Black, Living in the Red: Race, Wealth, and SOCIAL POLICY IN AMERICA 55-81 (1999); SHAPIRO, supra note 13, at 155-82.

15. See ShAPIRO, supra note 13, at xi, 2-3.

16. See, e.g., U.S. Comm'N On Civil Rights, The Economic Stagnation of the Black MidDle Class 1, 7-8 (2005), available at http://www.usccr.gov/pubs/122805 BlackAmericaStagnation.pdf; OLIVER \& SHAPIRO, supra note 13, at 23-24; JESSIE SMITH \& CARrell Horton, Statistical ReCord of Black America (4th ed. 1997). See generally Mary E. PATTILlO-MCCOY, Black PiCKET FenCES (1999).

17. See U.S. COMM'N ON Civil Rights, supra note 16, at 9; Oliver \& ShaPiro, supra note 
the circumstances of families and individuals in the black middle class are considerably more precarious; they are concentrated in lower middle class occupations and have less wealth and other economic resources on which to fall back. ${ }^{18}$

To maintain the type of racial system described in broad sweep above, specific structures must be in place within and across institutions. In the United States, residential segregation and the organization of the housing market that supports continued segregation is a key mechanism undergirding the existing hierarchy. ${ }^{19}$ The long history of housing market discrimination by race and place created and reinforced ethnoracial segregation. ${ }^{20}$ Historical policies and practices, including restrictive covenants and Federal Housing Administration/Veteran's Administration lending policies (e.g., redlining, minimum unit and lot standards), supported the development of white neighborhoods and suburban localities. ${ }^{21}$ Real estate blockbusting ensured that inner city neighborhoods rapidly turned from white to black. ${ }^{22}$

Although these types of practices are now illegal, discriminatory actions that help to maintain segregated residential patterns persist. Factors that underlie continued segregation include: blacks and others receiving less information than whites about available housing; nonwhite and white renters and homebuyers being steered to neighborhoods with racial compositions that reflect their own race/ethnicity; and persistent discrimination in mortgage lending (e.g., higher rates of interest, loan denials, and subprime loans for blacks more so than whites). ${ }^{23}$ Lower levels of housing appreciation in black and Latino than

13 , at $23-24$.

18. See generally Karyn R. Lacy, Blue-Chip Black: Race, Class, and Status in the NEW BlaCK MidDle Class 21-50 (2007).

19. See, e.g., Bonilla-Silva, White Supremacy, supra note 2, at 95-96; Douglas S. Massey \& Nancy A. Denton, American Apartheid: Segregation and the Making of the UNDERCLASS 83-114 (1993).

20. See, e.g., Kevin Fox Gotham, Race, Real Estate, and Uneven Development: The KANSAS CITY EXPERIENCE, 1900-2000, at 33-47 (2002); MASSEY \& DENTON, supra note 19, at 2642; Camille Zubrinsky Charles, The Dynamics of Racial Residential Segregation, 29 ANN. Rev. Soc. 167, 167-68 (2003); Stephen L. Ross \& Margery Austin Turner, Housing Discrimination in Metropolitan America: Explaining Changes Between 1989 and 2000, 52 SOC. PrOBLEMS 152, 15355 (2005).

21. See, e.g., Gotham, supra note 20 , at 37,57 .

22. See id. at 25; MASSEY \& DENTON, supra note 19, at 37-38.

23. John Yinger, Closed Doors, OpPortunities Lost: The CONTINUING Costs OF Housing Discrimination 31 (1995); see, e.g., STEPHEN Ross \& JOHN Yinger, THE COlOR OF CREdit: Mortgage Discrimination, Research Methodology, AND FAir-LENDing 5-8 (2002) ("[M]ortgage loan applications from black and Hispanic households are still much more likely to be 
white neighborhoods ${ }^{24}$ also decrease the housing wealth accumulation of groups of color and limit the ability of such groups to move to white areas where housing is more valuable. Segregation is further supported by white racist attitudes. ${ }^{25}$ Whites are highly resistant to living in neighborhoods with many black residents and also seek to avoid living with many Hispanics and Asians, although to a lesser degree. ${ }^{26}$

The results of these practices are dramatic levels of residential separation of whites from blacks. ${ }^{27}$ The most commonly used measure of black-white residential segregation shows that in 2000, an average of $65.2 \%$ of metropolitan blacks (or whites) would have to move to a different neighborhood to achieve an even residential distribution. ${ }^{28}$ This reflects steady but slight declines in black-white segregation since $1970{ }^{29}$ The largest decreases in segregation have been in metropolitan areas with small black populations where the potential for whites having contact with blacks is modest. ${ }^{30}$ Residential segregation of whites from Hispanics and Asians is more moderate, but remained essentially stable

denied than applications from whites."); Carolyn Bond \& Richard Williams, Residential Segregation and the Transformation of Home Mortgage Lending, 86 SOC. FoRCES 671, 677-80 (2007) ("[L]oans with less favorable terms and higher foreclosure rates may also have less impact, or even a negative impact, in integrating neighborhoods"); Ross \& Turner, supra note 20, at 176-77 ("[S]teering by real estate agents limits the options of minority home seekers and can perpetuate the currently high levels of racial segregation in U.S. metropolitan areas.").

24. See, e.g., Chenoa Flippen, Unequal Returns to Housing Investments? A Study of Real Housing Appreciation Among Black, White, and Hispanic Households, 82 SOC. FORCES 1523, 1523, 1525-27, 1544 (2004) ("[H]igh levels of neighborhood minority concentration undermine housing appreciation.").

25. See, e.g., Camille Zubrinsky Charles, Won't You Be My Neighbor?: Race, Class, AND RESIDENCE IN LOS ANGELES 163-89 (2006) ("Whites continue to adhere to negative racial stereotypes, particularly toward blacks and Latinos, but to a lesser extent towards Asians as well.”).

26. See, e.g., Charles, supra note 20 , at $185-91$ (discussing prejudice as the reason for racially segregated neighborhoods versus alternative explanations); CHARLES, supra note 25, at 137-40 ("Whites' Neighborhood Racial Composition Preferences").

27. See, e.g., MASSEY \& DENTON, supra note 19, at 2 ("No group in the history of the United States has ever experienced the sustained high levels of residential segregation that has been imposed on blacks in large American cities for the past fifty years."); John R. Logan et al., Segregation of Minorities in the Metropolis: Two Decades of Change, 41 DEMOGRAPHY, Feb. 2004, at 1-2 ("[B]lacks faced a near-apartheid situation" in the 1970-1980 decade that "declined modestly ... after 1980."); Rima Wilkes \& John Iceland, Hypersegregation in the Twenty-First Century, 41 Demography, Feb. 2004, at 23.

28. Logan et al., supra note 27, at 6 (Table 1).

29. Claude S. Fischer et al., Distinguishing the Geographic Levels and Social Dimensions of U.S. Metropolitan Segregation, 41 DEMOGRAPHY, Feb. 2004, at 47; see Logan et al., supra note 27, at 1 ("Would black-white segregation continue the slow decline that had begun by 1970 . . .?").

30. See, e.g., Lauren J. Krivo \& Robert L. Kaufman, How Low Can It Go? Declining BlackWhite Segregation in a Multiethnic Context, 36 DEMOGRAPHY, Feb. 1999, at 94; Logan et al., supra note 27 , at 2 . 
from 1980 to 2000 due to the continuous flow of in-migrants into existing immigrant and ethnic communities. ${ }^{31}$

Residential segregation of ethnoracial groups from each other is highly consequential because separate is still not equal. ${ }^{32}$ The neighborhoods in which people live provide them with access (or the lack thereof) to a wide range of important social and institutional resources. For example, school attendance is generally connected to one's neighborhood location, ${ }^{33}$ and schools vary widely in their physical and academic quality in ways that are closely connected to the economic and racial composition of neighborhoods. ${ }^{34}$ Political representation and government services depend on residential location and the distribution of local services including street lights, trash collection, police service, libraries, and the like, are highly inequitably distributed across neighborhoods and municipalities. ${ }^{35}$ Wealth accumulation is also linked with residential location because housing equity is the single largest source of wealth for households. ${ }^{36}$ Home values and housing appreciation (major contributors to housing wealth) are influenced by the racial composition of the neighborhood, with housing wealth accumulating more slowly in heavily black and Latino neighborhoods. ${ }^{37}$ Furthermore, within a racially structured society, a range of organizations such as businesses and lending agencies make decisions about where to invest institutional and economic resources partially based upon the racial composition of neighborhoods. Predominantly white areas often receive more economic and social investments that are

31. See, e.g., Logan et al., supra note 27, at 1 ("Increases in Hispanic and Asian segregation in individual metropolitan areas were counterbalanced by a net movement of these two groups towards areas of lower segregation. These increases were associated especially with the more rapid growth in the Hispanic and Asian populations.").

32. See, e.g., MASSEY \& DENTON, supra note 19, at 13-14.

33. See generally Andrew Grant-Thomas \& john a. powell, Structural Racism and Color Lines in the United States, in Twenty-First CENTURy COlOR Lines: Multiracial Change IN CONTEMPORARY AMERICA 118 (Andrew Grant-Thomas \& Gary Orfield eds., 2009).

34. Dennis J. Condron \& Vincent J. Roscigno, Disparities Within: Unequal Spending and Achievement in an Urban School District, 76 Soc. OF EDUC. 18, 33 (2003).

35. See, e.g., Robert D. Bullard, Introduction: The Significance of Race and Place, in THE Black Metropolis in the Twenty-First Century: Race, Power, and Politics of Place 1, $2-$ 4 (Robert D. Bullard ed., 2007); Robert D. Bullard, Introduction: Anatomy of Sprawl, in SPRAWL City: Race, Politics, AND PlanNing in ATlanta 2-4 (Robert D. Bullard et al. eds., 2000).

36. See, e.g., Alfred O. Gottschalck, U.S. Census Bureau, U.S. DeP'T of Com., Series P-70-115, Net Worth AND the ASSETS of Households, Current Population ReP., Household Econ. Stud. 4 (2008); SANDRA LuCKett, U.S. BurEau of The Census, U.S. DeP'T of Com., Series P-70-75, Did You KnOw? Homes ACCount For 44 Percent of All Wealth: Findings FrOM THE SiPP, CurRent Population ReP., Household ECON. Stud. 2 (2001); Edward N. Wolff, Recent Trends in the Size Distribution of Wealth, 12 J. ECON. PERSP. 131, 137 (1998).

37. See, e.g., Flippen, supra note 24, at 1535. 
also of higher value while communities of color are more likely neglected and/or targeted for disinvestments and placement of disruptive institutions. $^{38}$

Massey and Denton have argued and shown that residential segregation serves to channel the racial inequality in rewards (e.g., high income) and disadvantages (e.g., poverty) evident in a racially stratified society into distinct neighborhood environments. ${ }^{39}$ Large racial and ethnic differences in income and poverty that emanate from the labor market, for example, produce large differences in the economic status of white, black, and other neighborhoods of color under conditions of residential segregation. ${ }^{40}$ In particular, segregation concentrates white economic (and other) advantages within white neighborhoods. ${ }^{41}$ Conversely, black areas are mired in multiple disadvantages because segregation concentrates the higher levels of black poverty, joblessness, and the like within predominantly black neighborhoods. ${ }^{42}$ Given more modest segregation, levels of disadvantage in other neighborhoods of color reflect the position of such groups in the social hierarchy-most often between that of blacks and whites. ${ }^{43}$

\section{VIOLENT CRIME IN A RACIALLY STRUCTURED SOCIETY}

How do the racialized neighborhood patterns that are supported through segregation connect with ethnoracial differences in levels of violent crime? Perspectives on neighborhood crime contend that local conditions produce social environments that encourage (or discourage)

38. See, e.g., Arnold R. Hirsch, Making the Second Ghetto: Race And Housing IN Chicago, 1940-1960 (1983); Deborah Wallace \& Rodrick Wallace, A Plague on Your Houses: How New York Was Burned Down and National Public Health Crumbled 9-10 (1998); Steven R. Holloway \& Elvin K. Wyly, “The Color of Money” Expanded: Geographically Contingent Mortgage Lending in Atlanta, 12 J. Housing RES. 55, 58-60 (2001); Elvin K. Wyly \& Steven R. Holloway, "The Color of Money" Revisited: Racial Lending Patterns in Atlanta's Neighborhoods, 10 HOUSING POL'Y DEBATE 555, 557-58 (1999).

39. See generally MASSEY \& DENTON, supra note 19.

40. See, e.g., Paul A. Jargowsky, Poverty and Place: Ghettos, Barrios, And the AMERICAN CITY 3 (1997); Lauren J. Krivo et al., Race, Segregation, and the Concentration of Disadvantage: 1980-1990, 45 Soc. Problems 61, 62 (1998); Douglas S. Massey \& Mary J. Fischer, How Segregation Concentrates Poverty, 23 ETHNIC \& RACIAL STUD. 670, 671 (2000); Douglas S. Massey \& Mitchell L. Eggers, The Ecology of Inequality: Minorities and the Concentration of Poverty, 1970-1980, 95 AM. J. SoC. 1153, 1168-69 (1990); cf. Lincoln Quillian, The Decline of Male Employment in Low-Income Black Neighborhoods, 1950-1990, 32 SoC. SCI. RES. 220, 244-46 (2003).

41. See Massey \& Fischer, supra note 40, at 671; Quillian, supra note 40, at 244-46.

42. See sources cited supra note 41.

43. See generally Massey \& Fischer, supra note 40, at 687-89. 
and control (or fail to control) violence. ${ }^{44}$ A common argument is that violence is heightened in neighborhoods that are highly disadvantaged and residentially unstable because the processes that encourage criminal behavior are particularly prevalent. ${ }^{45}$ Further, the mechanisms of social control that normally serve to discourage violent crime are especially lacking because it is difficult for communities to organize to promote common goals and facilitate the control of violence. ${ }^{46}$

Elaborating on processes that encourage crime, residents of disadvantaged and unstable neighborhoods may be socialized to engage in violence through modeling the actions of others. ${ }^{47}$ They witness more violent acts and have a greater number of "role models who do not restrain their" own anger and frustration. ${ }^{48}$ As a result, violence is a more common aspect of everyday life. Residents must adapt to the heightened possibility of violent encounters, which encourages further violence. ${ }^{49}$ That is, community members must use, or appear ready to use, violence "to defend their lives and property." ${ }^{\circ}$ As more people "adopt defensive and threatening postures" and behaviors such as carrying weapons, "the level of violence escalates" and the number of people who rely upon violence for defensive purposes increases. ${ }^{51}$ Role modeling and adaptation processes may be particularly potent in disadvantaged communities because of widespread joblessness and irregular employment. Thus, many who reside in these neighborhoods

44. See, e.g., Elijah Anderson, Code of the Street: Decency, Violence, and the MORAL LIFE OF THE INNER CITY 9-11 (1999) [hereinafter ANDERSON, CODE OF THE STREET]; William Julius Wilson, When Work DisapPEARS: The World of the NeW URBan POOR at xiii (1996) [hereinafter WILSON, WHEN WORK DISAPPEARS]; Ruth D. Peterson et al., Segregation and Race/Ethnic Inequality in Crime: New Directions, in TAKING STOCK: THE STATUS OF Criminological Theory 169, 169 (Cullen et al. eds., 2006); Robert J. Sampson et al., Neighborhoods and Violent Crime: A Multilevel Study of Collective Efficacy, 277 SCIENCE 918 (1997); Sampson \& Wilson, supra note 1, at 38. See generally EliJAH ANDERSON, STREETWISE: Race, Class, and Change in AN URban COMMUnity (1990) [hereinafter ANDERSON, Streetwise]; Clifford R. ShaW \& Henry D. McKay, Juvenile Delinquency and Urban AREAS (rev. ed. 1969); William Julius Wilson, The Truly Disadvantaged: THE INNER City, the Underclass, and Public Policy (1987) [hereinafter Wilson, TRUly Disadvantaged]; Christopher R. Browning et al., The Paradox of Social Organization: Networks, Collective Efficacy, and Violent Crime in Urban Neighborhoods, 83 SOC. FORCES 503 (2004).

45. See, e.g., ANDERSON, CODE OF THE STREET, supra note 44, at 9-11; Wilson, WHEN WORK DisAPPEARS, supra note 44, at xiii; Krivo \& Peterson, supra note 1, at 621; Peterson et al., supra note 44, at 175; Sampson \& Wilson, supra note 1, at 38. See generally ANDERSON, STREETWISE; WILSON, WHEN WORK DISAPPEARS, supra note 44.

46. Peterson et al., supra note 44, at 175.

47. Id.

48. $I d$.

49. Id.

50. Id.

51. Id. at 176 . 
"are idle for large parts of the day.,"52 Idle individuals may "spend significant amounts of time in settings where non-conventional role modeling and defensive posturing are prevalent-local taverns, pool halls and street corners." ${ }^{, 3}$ Thus, "they are involved in "situations of company" that may be "conducive" to violence. ${ }^{54}$

It is also more difficult to maintain effective social control because disadvantaged and unstable neighborhoods are characterized by a high degree of social isolation from mainstream society. ${ }^{55}$ As such, residents have less exposure to conventional role models and are less likely to have jobs. There are fewer "old heads" that provide anti-crime, antitrouble lessons, and those that remain no longer have prestige and credibility as role models. ${ }^{56}$ Disadvantaged neighborhoods also have relatively few working- and middle-class families to serve as social buffers cushioning the effects of uneven and poor economic conditions. ${ }^{57}$ "This impedes the ability of communities to sustain basic institutional structures" and various sources of social control. ${ }^{58}$ Similarly, residential instability is thought to inhibit the emergence of viable social networks and to weaken attachments to local communities. ${ }^{59}$ This hinders efforts to mobilize local residents to provide informal social control of neighborhood life. ${ }^{60}$ Diminished social control may also result from "inadequate police protection, i.e., insufficient supply and deployment of police, failure to respond to calls from residents, or slow and irregular responses by the police. As a result, the costs associated with engaging in ... violence are lessened and the possible deterrent effect of the law is reduced." ${ }^{61}$ In short, residents of disadvantaged and unstable communities lack adequate financial, social, and institutional resources to effectively prevent and fight violent crime. ${ }^{62}$

\footnotetext{
52. Id.

53. $I d$.

54. Id.

55. Id. at 170 .

56. Id. at 175 .

57. $I d$.

58. Id.; see also Ruth D. Peterson et al., Disadvantage and Neighborhood Violent Crime: Do Local Institutions Matter?, 37 J. RES. IN CRIME \& DELINQ. 31, 32 (2000) ("Disadvantaged neighborhoods have difficulty attracting and maintaining the types of local institutions that impede violent behavior by providing community stability, social control, and alternative activities to occupy the time of residents.").

59. Peterson et al., supra note 44, at 175.

60. Id.

61. Id.

62. Id. (citing Robert J. Bursik, JR. \& HAROld G. GRASMiCK, NeIGHBorhoOdS AND CRIME: THE DimENSIONS OF EFFECTIVE COMMUNITY CONTROL 4-5 (1993)).
} 
As noted above, outside agents respond in distinct ways to varying communities of color. External investors favor white neighborhoods and tend to neglect black and other non-white areas. Substantial external investments help neighborhoods, while their absence creates sizable challenges for the physical appearance and economic viability of community structures. ${ }^{63}$ Neighborhoods in which the infusion of resources, e.g., loans to purchase and maintain residential properties, is relatively lacking have difficulty repairing dilapidated housing, recruiting new home buyers, sustaining existing businesses, and attracting new businesses. As a result, physical deterioration and disorder are enhanced, both of which have been linked to violence. ${ }^{64}$ Further, limited outside investments may increase criminogenic conditions such as diminished local economic opportunities, weakened local social ties, and deteriorated community institutions like schools and churches. ${ }^{65}$ By contrast, substantial outside investments signal the presence of powerful political and economic connections that allow communities to fight potential threats that could lead to violence. ${ }^{66}$

A final neighborhood condition that is relevant for violence and that varies substantially across ethnoracially distinct neighborhoods is the prevalence of immigrants. Historically, social disorganization theory contended that large immigrant populations contribute to crime and violence through the same mechanisms as disadvantage and residential instability. ${ }^{67}$ The presence of large numbers of immigrants was considered to undermine social control by making it difficult for

63. See sources cited supra note 44.

64. Wesley G. Skogan, Disorder and Decline: Crime and the Spiral of DeCAy iN AmERICAN NeIGHBorhoods 2-3 (1990); see GeOrge L. KElling \& CATHERINe M. Coles, FiXing BROKEN WINDOWS: RESTORING ORDER AND REDUCING CRIME IN OUR COMMUNITIES 19 (1996); $c f$. RALPH B. TAYLOR, BREAKING AWAY From BROKEN WindOWS: BALTIMORE NEIGHBORHOODS AND the Nationwide Fight Against Crime, Grime, Fear, And Decline 6-23 (2001); Robert J. Sampson \& Stephen W. Raudenbush, Systematic Social Observation of Public Spaces: A New Look at Disorder in Urban Neighborhoods, 105 AM. J. SoC. 603, 605 (1999) (applying a different method "to the study of social and physical disorder in urban neighborhoods ... as an alternative to the 'broken windows' interpretation of the disorder-crime link").

65. See generally TAYLOR, supra note 64

66. See generally María B. Vélez, The Role of Public Social Control in Urban Neighborhoods: A Multilevel Analysis of Victimization Risk, 39 CRIMINOLOGY 837, 837-64 (2001) [hereinafter Vélez, The Role of Public Social Control]; María B. Vélez, Toward an Understanding of the Lower Rates of Homicide in Latino Versus Black Neighborhoods: A Look at Chicago, in THE MANY COLORS OF CRIME: INEQUALITIES OF RACE, ETHNICITY AND CRIME IN AMERICA 91, 91-107 (Ruth D. Peterson et al. eds., 2006) [hereinafter Vélez, Homicide in Latino Versus Black Neighborhoods].

67. E.g., SHAW \& MCKAY, supra note 44, at 374-75; see Ramiro Martinez, Jr., Coming to America: The Impact of the New Immigration on Crime, in IMMIGRATION AND CRIME: RACE, ETHNiCity, AND Violence 1, 1-15 (Ramiro Martinez, Jr. \& Abel Valenzuela, Jr. eds., 2006) (providing a summary of this perspective). 
community residents to organize to solve common problems. Yet, recent studies challenge this contention in that they demonstrate consistently lower rates of violent crime in communities with more immigrants. ${ }^{68}$ The exact mechanisms that account for this relationship are not fully understood. However, Martinez argues that Latino and immigrant communities evidence relatively high levels of labor market attachment (albeit employment in menial jobs), a factor that should reduce involvement in violence. ${ }^{69}$ In addition, neighborhoods with more immigrants may exhibit less violent crime because large portions of the population use communities of origin as frames of reference in evaluating their circumstances. $^{70}$ As deprived as conditions may be in U.S. barrios and other immigrant areas, conditions may be even worse in residents' countries of origin, thus nullifying potential higher levels of violence that stem from reactions to ascriptive inequality in a purportedly open society. ${ }^{71}$

A large body of research has evaluated the role of structural community conditions in accounting for variation in rates of violent crime. $^{72}$ This research has shown clear links between the factors described above and neighborhood violence. ${ }^{73}$ However, little of this work has explored the connections of glaring divisions in community conditions with differences in violence across communities of distinct

68. E.g., Vélez, Homicide in Latino Versus Black Neighborhoods, supra note 66, at 95. See generally RAMIRO MARTINEZ, JR., LATINO HOMICIDE: IMMIGRATION, VIOLENCE AND COMMUNITY (2002); Matthew T. Lee et al., Does Immigration Increase Homicide? Negative Evidence From Three Border Cities, 42 Soc. Q. 559 (2001); Robert J. Sampson, Rethinking Crime and Immigration, 7 CONTEXTS 28 (2008).

69. MARTINEZ, supra note 68, at 6 ("Latinos have lower homicide rates than expected... because they exhibit higher levels of social integration, as measured by labor market involvement, while simultaneously exhibiting elevated poverty rates. Latinos, heavily immigrant, are poor but working, and that influence shapes homicide.”); see also Vélez, Homicide in Latino Versus Black Neighborhoods, supra note 66, at 96.

70. MARTINEZ, supra note 68 , at 133.

71. For statements concerning the effect of ascriptive inequality on violence, see generally Steven F. MESSNER \& Richard ROSENFELD, CRIME AND THE AMERICAN DREAM (3rd ed. 2001) and Judith R. Blau \& Peter M. Blau, The Cost of Inequality: Metropolitan Structure and Violent Crime, 47 AM. Soc. REv. 114, 114-29 (1982).

72. See generally SHAw \& MCKAY, supra note 44; Browning et al., supra note 44; Krivo \& Peterson, supra note 1; McNulty, supra note 1; Jeffrey D. Morenoff et al., Neighborhood Inequality, Collective Efficacy, and the Spatial Dynamics of Urban Violence, 39 CRIMINOLOGY 517 (2001); Sampson et al., supra note 44. For reviews, see generally Travis C. Pratt \& Francis T. Cullen, Assessing Macro-Level Predictors and Theories of Crime: A Meta-Analysis, 32 CRIME AND JUST. 373 (2005) and Robert J. Sampson, Collective Efficacy Theory: Lessons Learned and Directions for Future Inquiry, in TAKING STOCK: THE StATUS OF CRIMINOlogical THEORY, supra note 44, at 149.

73. See generally SHAW \& MCKAY, supra note 44; Browning et al., supra note 44; Krivo \& Peterson, supra note 1; McNulty, supra note 1; Morenoff et al., supra note 72; Sampson et al., supra note 44 . 
colors. ${ }^{74}$ Further, analysts have not assessed and interpreted patterns in terms of the deeply embedded histories of privilege and oppression that are major sources of the creation and recreation of differential violence. This is a fundamental problem in providing a sound explanation for ethnoracial inequality in criminal violence because the racialized reality of the neighborhood structures is not a matter of neutral happenstance. Indeed, this reality is intricately embedded within much broader forces of social organization that are structured by race and class. Taking this as a core premise upon which we organize and interpret our analyses provides a more in-depth and meaningful understanding of racial disparities in violent crime than heretofore has been available.

\section{DATA AND METHODS}

\section{A. Data and Sample}

Given that communities of color are often very dissimilar in their existing social conditions because of the racialized structure of society, any influences of community context on violence are commonly conflated with unaccounted-for differences associated with racial composition. Thus, it is difficult to evaluate whether ethnoracial inequality in neighborhood violence (or other outcomes) is a product of the highly divergent local conditions as we argue. To deal with this problem, research must be designed so that neighborhoods that are ethnoracially distinct but relatively similar in socioeconomic and other conditions can be compared. The difficulty in doing so is that there are few highly impoverished and otherwise disadvantaged white urban neighborhoods, particularly ones that are as disadvantaged as many black communities in the United States. ${ }^{75}$ At the same time, there are very few black neighborhoods that are as affluent and widely advantaged as is commonly the case among white areas. ${ }^{76}$

We conducted the National Neighborhood Crime Study (NNCS) to address this comparability problem by collecting neighborhood data for many cities across the country. While any single city might have only one middle class black neighborhood and one highly disadvantaged

74. The exceptions are Krivo \& Peterson, supra note 1, and McNulty, supra note 1. For a more extended discussion of this point, see generally Ruth D. Peterson \& Lauren J. Krivo, Macrostructural Analyses of Race, Ethnicity, and Violent Crime: Recent Lessons and New Directions for Research, 31 ANN. REV. SOC. 331 (2005).

75. See, e.g., McNulty, supra note 1, at 468; Peterson \& Krivo, supra note 74, at 333.

76. See sources cited supra note 75 . 
white neighborhood, by including local areas across a large number of cities, our study yields a sample that has a sufficient number of ethnoracially distinct but otherwise comparable neighborhoods for addressing the interlinkages of interest here. The NNCS includes reported crime counts obtained directly from police departments, and social and demographic information from the U.S. Census and Home Mortgage Disclosure Act data for all census tracts $(\mathrm{N}=9593)$ within a representative sample of ninety-one U.S. cities (central cities and suburbs) with populations over 100,000 for the year $2000 .^{77}$ The cities in the sample include places in all regions of the country, those with declining and healthy economies, and cities that vary in their levels of racial residential segregation. The sample is highly representative of large cities (populations of at least 100,000), with means for the crime rate, black-white residential segregation, poverty, and racial composition for the sample differing by at most ten percent from the population of places with over 100,000 residents.

Our analysis is restricted to 8286 census tracts (i.e., neighborhoods) across eighty-seven cities for which complete information is available for the set of violent crimes analyzed here. We distinguish among four ethnoracial neighborhood types: predominantly white, predominantly black, predominantly Latino, and integrated. Neighborhoods are defined as predominantly white, black, or Latino if the respective group constitutes at least seventy percent of the tract population. Whites and blacks include only those who are non-Latino and Latinos include those of any census racial category. ${ }^{78}$ Tracts are considered integrated when none of the three panethnic groups is larger than seventy percent of the population and when blacks and Latinos together do not make up more than seventy percent of the population. The integrated tracts have much more of a balance of ethnoracial groups than the single group dominant tracts. ${ }^{79}$ The sample examined here includes 3115 white neighborhoods,

77. We needed to collect data directly from police departments for the NNCS because the only existing central repository of crime in the United States is provided through the Federal Bureau of Investigation's Uniform Crime Reporting (UCR) program. However, the UCR data are for entire agencies only, such as cities, counties, or other similar jurisdictions and do not include information for smaller area units (e.g., neighborhoods) within these jurisdictions.

78. In the U.S. Census, racial identification is obtained from a question that asks a person to select "one or more" of the categories listed on the census questionnaire. Responses include: White; Black, African American or Negro; American Indian or Alaska Native; a range of specific Asian or Pacific Island origin groups; or Some Other Race. Hispanic/Latino identification is obtained through a separate question that asks whether the person is Spanish/Hispanic/Latino. Thus, Latino identified individuals can be of any census racial identification. Census.gov, RACIAL AND ETHNIC CLASSIFICATIONS USED IN CENSUS 2000 AND BEYOND, http://www.census.gov/population/www/ socdemo/race/racefactcb.html.

79. Mixed minority neighborhoods where the combination of blacks and Latinos makes up 
1467 black neighborhoods, 679 Latino neighborhoods, and 3025 integrated neighborhoods.

\section{B. Variables and Operationalizations}

The operationalizations for all variables are presented in Table 1. The dependent variable is a three-year average count (1999-2001) of violent crimes (homicides and robberies) reported to the police. ${ }^{80} \mathrm{We}$ use multi-year counts to minimize the impact of annual fluctuations for small units. Substantively, we are interested in predicting rates of reported violent crime, and do this through the use of non-linear multilevel modeling. ${ }^{81}$ Neighborhood characteristics include residential instability, residential loans, immigration, and socioeconomic disadvantage. Residential instability is measured with an index (average z-scores) combining the percent of renter-occupied units and the percent of residents aged five or older who lived in a different dwelling in 1995 $(\alpha=.69)$. Residential loans are measured as the total dollar amount (in $\$ 1000$ ) of home mortgages originated in the census tract in 2000 (logged due to skewness). They include conventional, Federal Housing Administration, and Veterans Administration loans for single or multifamily home purchases, home improvements, or refinancing. Immigrant prevalence is represented by an index (average z-scores) comprised of three variables: the percent of the total population that is foreign born, the percent of the total population that is foreign born and arrived in the U.S. in 1990 or later, and the percent of households in which no one age fourteen and over speaks English well $(\alpha=.96)$. Disadvantage is an index (average z-scores) of the extent of joblessness, professional or managerial occupations (reverse coded), high school graduates (reverse coded), female-headed families, secondary sector workers (those in the six occupations with the lowest average incomes $),{ }^{82}$ and poverty $(\alpha=.93)$.

seventy percent or more of the population (but neither group alone is more than seventy percent) are excluded.

80. Aggravated assaults are not included because the data obtained from police departments for this crime are missing for a substantial number of places due to problems of poor data quality.

81. See infra Part IV.C.

82. The lowest wage occupations were determined based upon mean national wage data by occupation for the thirty-three occupational categories for which such data are available for tracts. The national wage data were derived from 2000 census information obtained from the Integrated Public Use Microdata Series. See generally Daniel H. Weinberg, U.S. Census Bureau, EVIDENCE From Census 2000 About Earnings by Detailed Occupation for Men and WOMEN 6 (2004), http://usa.ipums.org/use/voliii/pubdocs/2000/censr-15.pdf. The six occupations 
We include the percent of residents who are male and between fifteen and thirty-four years old to control for the crime-prone population.

Table 1: Operationalizations, Means, and Standard Deviations of

\begin{tabular}{|c|c|}
\hline Variables & Operationalizations \\
\hline $\begin{array}{l}\text { Dependent Variable } \\
\text { Violent Crimes }\end{array}$ & $\begin{array}{l}\text { Three year (1999-2001) average number of homicides } \\
\text { robberies per } 1000 \text { tract population }\end{array}$ \\
\hline Independent Variables & \\
\hline \multirow[t]{5}{*}{ Nghd. Race/Ethnic Comp. } & Dummy variables for type of area: \\
\hline & $\begin{array}{l}\text { White Nghd., } 1=70 \% \text { or more non-Hispanic white } \\
(\text { else }=0)\end{array}$ \\
\hline & $\begin{array}{l}\text { Black Nghd., } 1=70 \% \text { or more non-Hispanic black } \\
(\text { else }=0)\end{array}$ \\
\hline & Latino Nghd., $1=70 \%$ or more Hispanic $(\mathrm{else}=0)$ \\
\hline & $\begin{array}{l}\text { Integrated Nghd., } 1=\text { Any other race/ethnic } \\
\text { combination }(\mathrm{else}=0)\end{array}$ \\
\hline \multirow{3}{*}{$\begin{array}{l}\text { Residential Instability } \\
(\alpha=.69)\end{array}$} & Average of the standard scores for two variables: \\
\hline & $\begin{array}{l}\% \text { of occupied housing units that are renter- } \\
\text { occupied }\end{array}$ \\
\hline & $\begin{array}{l}\% \text { of population age } 5 \text { and over who lived in a } \\
\text { different residence in } 1995\end{array}$ \\
\hline Residential Loans & Total dollar amount of loans originated (in $\$ 1000$ ) \\
\hline \multirow{4}{*}{$\begin{array}{l}\text { Immigrant Prevalence } \\
(\alpha=.96)\end{array}$} & Average of the standard scores of the following three variables: \\
\hline & $\%$ of the total population that is foreign born \\
\hline & $\begin{array}{l}\% \text { of the total population that is foreign born and } \\
\text { arrived in the U.S. in } 1990 \text { or later }\end{array}$ \\
\hline & $\begin{array}{l}\% \text { of households in which no one age } 14 \text { and over } \\
\text { speaks English well }\end{array}$ \\
\hline
\end{tabular}

included are: food preparation and serving-related occupations; personal care and service occupations; farming, fishing, and forestry occupations; building and grounds cleaning and maintenance occupations; health care support occupations; and material moving workers. This group of occupations is similar to that included in indicators of secondary sector work used in studies of labor stratification and violent crime. See, e.g., Robert D. Crutchfield et al., A Tale of Three Cities: Labor Markets and Homicide, 32 Soc. FocUS 65, 69 (1999); Lauren J. Krivo \& Ruth D. Peterson, Labor Market Conditions and Violent Crime Among Youth and Adults, 47 SOC. PERSP. 485, 492 (2004). 


\begin{tabular}{|c|c|}
\hline \multirow[t]{7}{*}{ Disadvantage $(\alpha=.93)$} & Average of the standard scores for six variables: \\
\hline & $\begin{array}{l}\% \text { of population } 16-64 \text { who are unemployed or out } \\
\text { of the labor force (joblessness) }\end{array}$ \\
\hline & $\begin{array}{l}\% \text { of employed civilian population age } 16 \text { and over } \\
\text { working in professional or managerial occupations } \\
\text { (reverse coded in index) }\end{array}$ \\
\hline & $\begin{array}{l}\% \text { of population age } 25 \text { and over who are college } \\
\text { graduates (reverse coded in index) }\end{array}$ \\
\hline & $\%$ of households that are female-headed families \\
\hline & $\begin{array}{l}\% \text { of employed civilian population age } 16 \text { and over } \\
\text { employed in the six occupational categories with } \\
\text { the lowest average incomes }\end{array}$ \\
\hline & $\%$ of population that is below the poverty line \\
\hline Percent of Males 15-34 & Percent of the population that is male age $15-34$ \\
\hline \multicolumn{2}{|l|}{$\begin{array}{l}\text { Independent Variables } \\
\text { City Level }(N=87)\end{array}$} \\
\hline Segregation & $\begin{array}{l}\text { Index of Dissimilarity across census tracts within the city between } \\
\text { non-Hispanic whites and non-Hispanic blacks }\end{array}$ \\
\hline \multirow[t]{7}{*}{ Disadvantage $(\alpha=.94)$} & Average of the standard scores for six variables: \\
\hline & $\begin{array}{l}\% \text { of population } 16-64 \text { who are unemployed or out } \\
\text { of the labor force (joblessness) }\end{array}$ \\
\hline & $\begin{array}{l}\% \text { of employed civilian population age } 16 \text { and over } \\
\text { working in professional or managerial occupations } \\
\text { (reverse coded in index) }\end{array}$ \\
\hline & $\begin{array}{l}\% \text { of population age } 25 \text { and over who are college } \\
\text { graduates (reverse coded in index) }\end{array}$ \\
\hline & $\%$ of households that are female-headed families \\
\hline & $\begin{array}{l}\% \text { of employed civilian population age } 16 \text { and over } \\
\text { employed in the six occupational categories with } \\
\text { the lowest average incomes }\end{array}$ \\
\hline & $\%$ of population that is below the poverty line \\
\hline Manufacturing Jobs & $\begin{array}{l}\text { Percent of employed civilian population age } 16 \text { and over working in } \\
\text { a manufacturing industry }\end{array}$ \\
\hline Population & Total city population \\
\hline Percent Black & Percent of the city population that is non-Hispanic black \\
\hline Percent Movers & $\begin{array}{l}\text { Percent of the population age } 5 \text { and over who lived in a different } \\
\text { residence in } 1995\end{array}$ \\
\hline Percent Foreign Born & Percent of the population that is foreign born \\
\hline Percent Young Males & Percent of the population that is male age $15-34$ \\
\hline South & Dummy for 1 if South (0 if else) \\
\hline West & Dummy for 1 if West ( 0 if else) \\
\hline
\end{tabular}

In multivariate models, characteristics of cities in which the census tracts are located are also controlled: black-white residential segregation, city disadvantage (measured in a parallel fashion to the neighborhood 
indicator), percent manufacturing jobs, population size, percent nonLatino black, percent of recent movers, percent foreign born, percent young males, and region. Racial residential segregation is measured with the widely used Black-White Index of Dissimilarity $(D)$ for census tracts within the city. ${ }^{83} D$ measures the extent of deviation from evenness of blacks and whites across areas within the city. It ranges from zero to one hundred with values representing the percent of blacks (or whites) who would have to change their tract of residence to achieve perfect integration. For example, in Chicago (the most segregated city in our sample), the Index of Dissimilarity is 85.2 , indicating that just over $85 \%$ of blacks (or whites) in this city would have to move to a different neighborhood for Chicago to become completely integrated.

\section{Methods of Analysis}

The analysis proceeds in several stages. We begin by describing the extent of residential separation of whites, blacks, and Latinos in the places studied here. Next, we examine patterns of differentiation in neighborhood conditions and violent crime across the four ethnoracial neighborhood types. Finally, we explore the net contribution of neighborhood social conditions in accounting for ethnoracial inequality in neighborhood violent crime using multivariate models that control for neighborhood age-sex composition and the relevant city violence predictors noted above. In particular, we estimate multilevel models with tracts as level-one units and cities as level-two units (representing tracts as cases that are embedded within cities as contexts). Because we are analyzing relatively rare events within small units, we estimate a nonlinear Poisson model (with overdispersion) with counts of violent crime as the outcome. We specify that these counts have variable exposure by

83. These data were acquired from the Lewis Mumford Center for Comparative Urban and Regional Research. 
tract population, and thereby make the analysis one of violence rates. ${ }^{84}$ All continuous variables are grand-mean centered.

V. RESULts

\section{A. Divergent Social Worlds}

The data from the NNCS demonstrate clearly the strong connections that exist between race-ethnicity and residential location in the urban United States. Indeed, these links are strong enough that ethnoracial groups in U.S. cities can be described as living in "divergent social worlds." Neighborhoods in which whites and blacks live are especially homogeneous. Figure 1 presents the percentages of white, black, and Latino individuals in the eighty-seven cities studied here who live in predominantly white, black, Latino, and integrated areas. Over sixty percent of whites in these large cities reside in communities in which their neighbors are mainly (seventy percent) other whites. Fifty-eight percent of blacks reside in areas where the vast majority of residents are black. A smaller but still sizable portion of Latinos (thirty-nine percent) have predominantly Latino neighbors. These racially distinct concentrations are the case even though only half of all residents of these cities are white, and about forty percent are either black $(21.2 \%)$ or Latino $(20.8 \%)$.

84. We use HLM 6.04 to fit our multi-level models. In non-linear Poisson models in HLM, the specification that crime counts have variable exposure by tract population is equivalent to specifying a Poisson model in which tract population is included as an independent variable with its parameter fixed at 1. A common concern in the application of the Poisson model is that it assumes equal mean and variance of the dependent variable. However, in the case of rare count events like those analyzed here, this assumption is frequently violated with the variance being considerably larger than the mean, i.e., there is overdispersion. See, e.g., D. Wayne Osgood, Poisson-Based Regression Analysis of Aggregate Crime Rates, 16 J. QUANT. CRIMINOLOGY 21, 28 (2000) (discussing overdispersion and offering solution using Poisson regression). In our analyses, we tested for overdispersion and found that it is significant. Hence, we control for overdispersion in the level-one variance. In hierarchical linear models, a Poisson model with overdispersion is analogous to a negative binomial model. 
Figure 1: Percentage of Ethnoracial Groups Living in Predominantly White, Black, Latino, and Integrated Neighborhoods

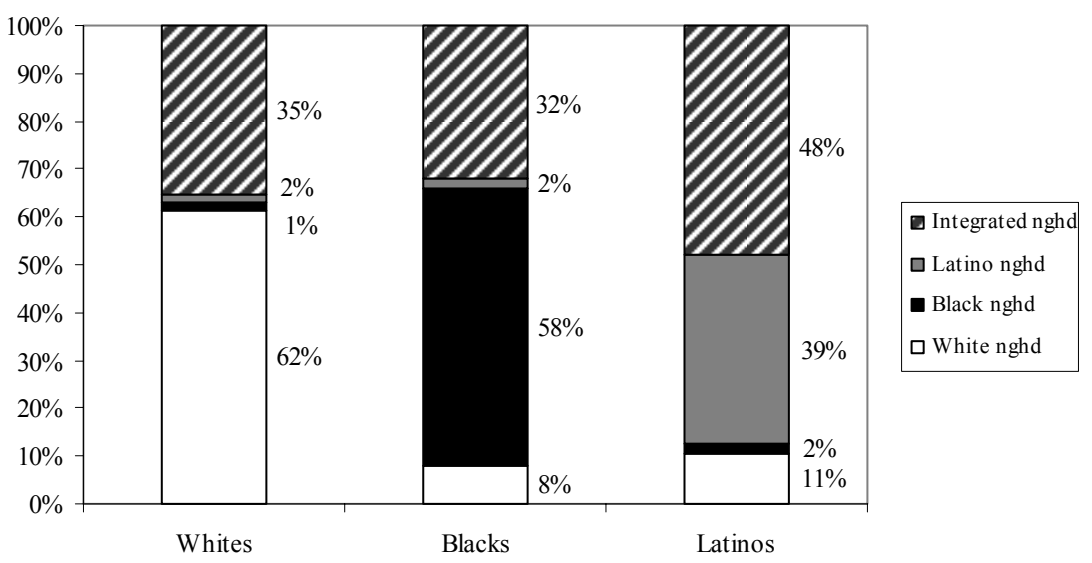

Residential separation is most dramatic for whites for whom only a trivial proportion live in areas with substantial numbers of either blacks (one percent) or Latinos (two percent). Still, blacks and Latinos also experience substantial separation from other groups with just ten percent of blacks and thirteen percent of Latinos living in neighborhoods with a large representation of either of the other two groups. Although neighborhood ethnoracial segregation is the norm for whites and for blacks, notable portions of all three groups do live in integrated neighborhood contexts in 2000. About one-third of whites and blacks and nearly half of Latinos reside in such areas.

While Figure 1 clearly shows stark ethnoracial residential separation alongside some tendency for groups to mix, it obscures the extreme isolation that exists for blacks compared to the other groups. Blacks are uniquely hypersegregated in the United States. ${ }^{85}$ To explore how this pattern is reflected in the data for the eighty-seven cities considered here, Figure 2 presents the percentage of each of the three ethnoracial groups that lives in neighborhoods that are comprised almost completely $(\geq$ ninety percent) of residents from the same group. This figure shows that a full thirty-nine percent of urban blacks in our sample live in neighborhoods that are almost exclusively comprised of other blacks.

85. See MASSEY \& DenTON, supra note 19, at 74-77; Wilkes \& Iceland, supra note 27, at 23 26. See generally Nancy A. Denton, Are African Americans Still Hypersegregated?, in RESIDENTIAL ApARTHEID: THE AMERICAN LEGACY 49, 49-81 (Robert D. Bullard et al. eds., 1994). 
This compares with just fourteen percent of whites and eleven percent of Latinos who live in areas with over ninety percent of their own group.

Figure 2: Percentage of Ethnoracial Groups Living in Neighborhoods With $90 \%$ or More of Same Race-Ethnicity

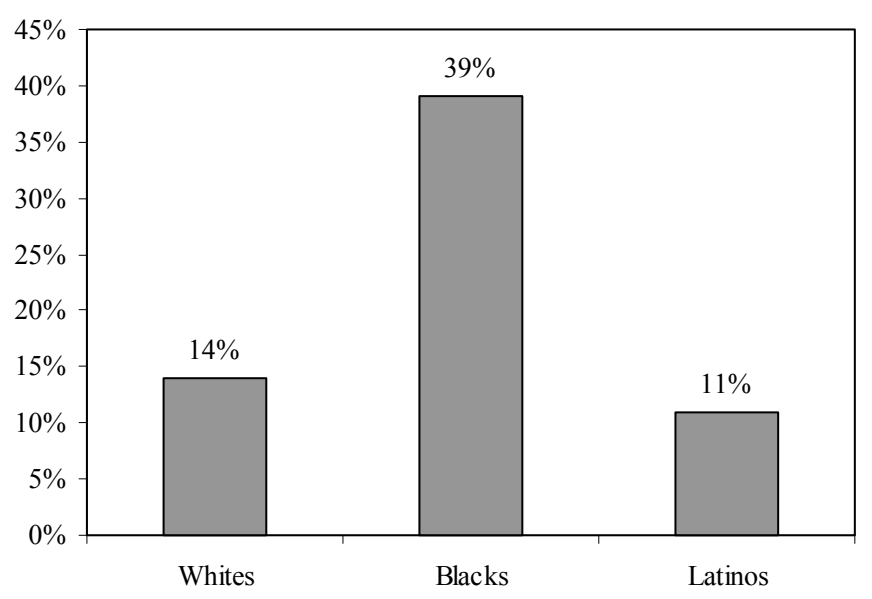

\section{B. Ethnoracial Neighborhood Inequality}

The residential separation of groups across neighborhoods is significant because the consequences are not neutral; that is, separate still is far from equal. In fact, white neighborhoods are highly advantaged and black and Latino neighborhoods are disadvantaged in a variety of ways. Figures 3 and 4 show how this inequality is reflected in the NNCS data for nearly 8300 neighborhoods across eighty-seven cities. Figure 3 reports the distribution of levels of neighborhood poverty for all white, black, Latino, and integrated neighborhoods. In this graph, low poverty neighborhoods are defined as those with twenty percent or fewer of residents below the poverty line; high poverty refers to areas where between twenty and forty percent of the population is in poverty; and extreme poverty neighborhoods have rates of forty percent or more. Overall, these data reveal striking differences across the ethnoracial neighborhood types.

Indeed, there is very little overlap in levels of poverty across areas of different ethnoracial compositions, with the differences being most extreme between blacks and whites. 
Figure 3: Percentage of Neighborhood Types By Levels of Neighborhood Poverty

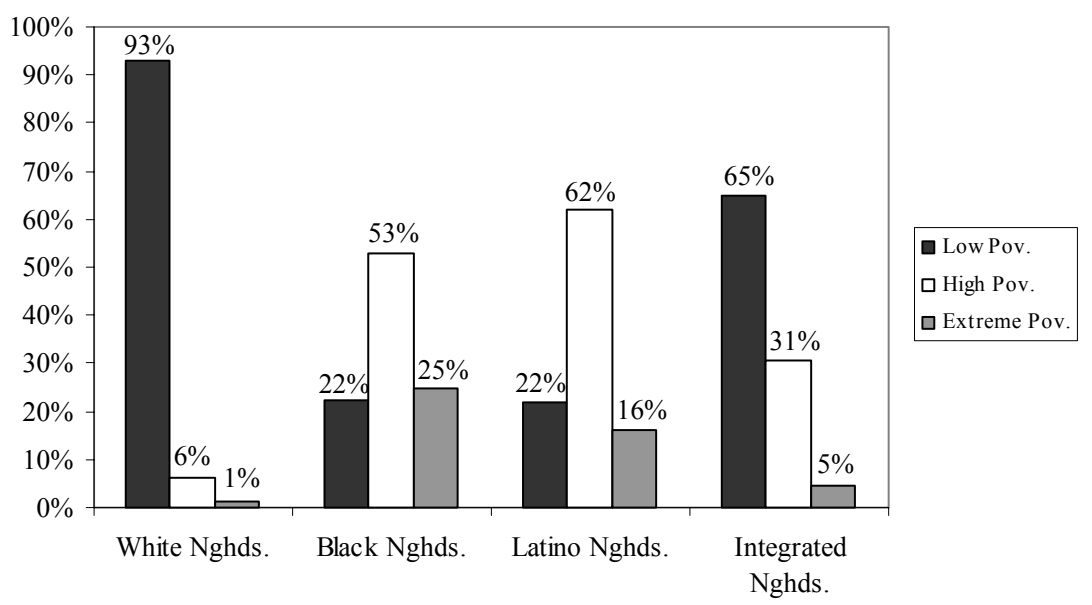

White urban neighborhoods are almost exclusively low poverty, with ninety-three percent falling in this category - only six percent have high poverty and a mere one percent are extremely impoverished. The difference in this distribution from that found among black neighborhoods is stark. Less than one-quarter of black neighborhoods have low levels of poverty while more than half (fifty-three percent) are high poverty areas. A full one-quarter of black neighborhoods are characterized by extreme levels of poverty. The neighborhood poverty distribution for Latino neighborhoods is quite similar to that for black areas; twenty-two percent have low poverty while sixty-two percent and sixteen percent have high and extreme poverty, respectively. Reflecting the mixture of populations, integrated neighborhoods fall between those for whites and the other two ethnoracial groups.

Figure 4 presents data comparing white and black areas in terms of the disadvantage index. Recall that this index summarizes where neighborhoods fall simultaneously across a set of socioeconomic neighborhood conditions. ${ }^{86}$ We present these data because neither poverty nor any other single characteristic stands alone in the real communities in which people live. Rather, a variety of adverse or favorable circumstances tend to coexist, forming constellations of disadvantage or advantage that comprise the contexts of people's lived communities. With the disadvantage index, a value of zero is average, 
positive values reflect ever greater levels of disadvantage, and values below zero show the inverse (i.e., more advantage).

Figure 4: Distributions of Disadvantage for White and Black

Neighborhoods

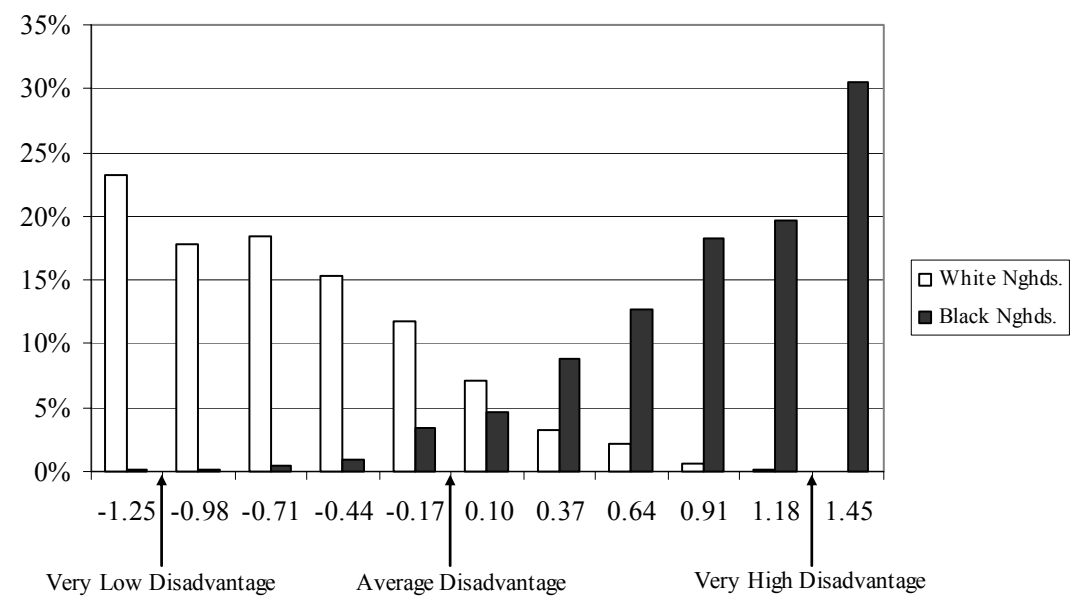

These data show that inequality between black and white neighborhoods is even more striking for overall disadvantage than for poverty alone. On the one hand, most white neighborhoods have below average disadvantage, with many having very low levels. On the other hand, virtually all of the black neighborhoods have above average disadvantage with a full thirty percent at the most extreme level of the disadvantage distribution. As a whole, the graph has a decidedly vshaped appearance because most white or black neighborhoods fall in the extremes of advantage/disadvantage rather than near the average. Indeed, very few neighborhoods, whether white or black, have levels of disadvantage that are near zero, making the notion of "average" disadvantage a misnomer. Rather, there are two distributions in which the "average" white and "average" black neighborhoods are nearly completely distinct from one another in their socioeconomic characterwhite neighborhoods being highly advantaged and black neighborhoods being heavily disadvantaged. Although not reported here, patterns for Latino compared to white neighborhoods are similar, but less extremely differentiated than the black-white comparison. The distribution of 
disadvantage for integrated neighborhoods appears to be a combination of the white and two predominantly non-white types of areas. ${ }^{87}$

Turning to inequality in violent crime across the ethnoracially distinct neighborhood types, Figure 5 shows patterns that, to some degree, correspond with the variation in socioeconomic conditions. Average violent crime rates are dramatically higher in neighborhoods of color than in white neighborhoods. ${ }^{88}$ The rate in white neighborhoods per thousand population is approximately two. The mean violence rate for black neighborhoods is five times higher at ten per thousand. The mean rates for Latino and integrated areas are nearly two and a half times that for white neighborhoods at just under five per thousand. The question addressed in the following section is whether these patterns hold when the full set of neighborhood and city characteristics that are associated with violent crime rates are taken into account.

Figure 5: Violent Crime Rates for Neighborhoods of Different Colors

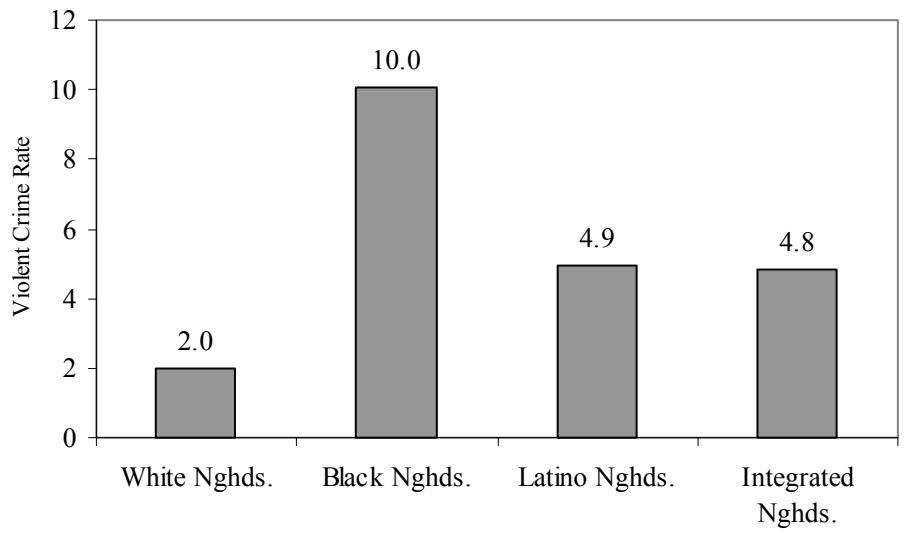

87. Other community characteristics are also highly variable across the ethnoracial neighborhood types. The patterns for these factors generally fall in line with those for disadvantage. Descriptive statistics for all of the community conditions included here by race-ethnicity of neighborhood are provided in Appendix A.

88. The violent crime rate is defined as the number of murders and robberies in the census tract per thousand population in the tract. 


\section{Evaluating the Links Between Violent Crime and Racialized Community Structure}

As noted above, we utilize statistical models that simultaneously take into account a variety of factors that are theoretically related to neighborhood violent crime and explore their contributions to differences in rates between white areas and black, Latino, and integrated neighborhoods. Table 2 presents the results from these models. In particular, the values in this table represent the ratio of the neighborhood violent crime rate in the average black, Latino, or integrated area to that in the average white area. The first row of values shows these ratios when controlling for neighborhood age-sex structure and city characteristics alone. Each row successively adds one of the theoretical neighborhood factors that is considered to be a major contributor to local violence. As discussed above, these factors are also racially structured across urban neighborhoods in the United States. To the degree that racialized social conditions contribute to ethnoracial inequality in violent crime, we anticipate that the reported violence ratios will fall closer to one as each additional neighborhood factor is taken into account.

Table 2: Ratios of Violent Crime Rates for Black, Latino, and Integrated Versus White Neighborhoods ${ }^{89}$

\begin{tabular}{lccc}
\hline \multicolumn{1}{c}{ Accounting For: } & $\begin{array}{c}\text { Black Area/ } \\
\text { White Area }\end{array}$ & $\begin{array}{c}\text { Latino Area/ } \\
\text { White Area }\end{array}$ & $\begin{array}{c}\text { Integrated Area/ } \\
\text { White Area }\end{array}$ \\
\hline 1. Control Factors & 4.29 & 2.48 & 2.24 \\
2. Residential Instability & 3.81 & 2.45 & 2.00 \\
3. Residential Loans & 3.28 & 2.13 & 1.90 \\
4. Immigration & 3.27 & 2.20 & 1.92 \\
5. Disadvantage & 1.78 & 1.39 & 1.47 \\
\hline
\end{tabular}

In an average city, violent crime in black neighborhoods is just over four and a quarter times that in white neighborhoods (control model, row 1). Violent crime in Latino areas is about two and a half times the rate in the average white neighborhood, while integrated areas have about two and a quarter the average white rate. When levels of residential instability are taken into account, the excess of violent crime in black and

89. All results control for neighborhood age structure and city racial residential segregation disadvantage, manufacturing jobs, population size, percent non-Latino black, percent of recent movers, percent foreign born, percent young males, and region. 
integrated compared to white neighborhoods is reduced only modestly (from 4.29 to 3.81 for the former and from 2.24 to 2.00 for the latter); the Latino-white difference in violence is unaffected. For each type of neighborhood, external investments, as reflected in greater residential loans, reduce the differentials further (comparing rows 2 and 3), with this change being more substantial for black and Latino than for integrated areas. Immigration is not a powerful part of the story in accounting for inequality in crime across distinct ethnoracial areas. The difference in average violence rates for each of the non-white compared to white neighborhoods is very similar before and after immigration is controlled for (comparing rows 3 and 4). Among the structural factors, disadvantage is the major condition that accounts for the much higher levels of violence evidenced in all types of non-white neighborhoods (comparing rows 4 and 5). Including disadvantage reduces the blackwhite ratio by about half. The reduction approaches forty percent for the Latino-white ratio, and is approximately one-quarter for the integratedwhite neighborhood comparison.

Clearly, racialized neighborhood structural factors go a long way in accounting for inequality in levels of violent crime across areas with distinct ethnoracial compositions. If dramatic differences in social circumstances by race did not exist in the United States, our data suggest that black neighborhoods would have rates of violence that are, on average, only seventy-eight percent higher than in white neighborhoods, not three hundred twenty-nine percent higher $([4.29-1.00] \times 100)$. Latino and integrated neighborhoods would have rates that are, respectively, just thirty-nine and forty-seven percent higher than in white areas, not more than twice as high (as shown in row 1). Despite such large reductions, racial privilege in violent crime rates for white communities still exists and is highly consequential.

\section{CONCLUSIONS}

White neighborhoods that are relatively free from violence, black neighborhoods that are steeped in violent crime, and communities of other colors that fall in between on the spectrum of violence provide a poignant picture of urban areas in the United States. In this Article, we sought to articulate and empirically explore how this dramatic pattern of inequality in one visible aspect of the urban experience is intricately interconnected with the ways in which the structure of U.S. society is broadly racialized. We contend that the privilege of low levels of violence in white communities versus the peril of oppressively high levels of violence in black (and to some degree other) neighborhoods is 
not a product of individual differences in tendencies toward violence. Rather, these inequalities are outgrowths of structural arrangements that favor whites and subordinate other racial groups, especially blacks. Racial residential segregation is one such arrangement. In particular, segregation serves to reinforce and maintain the racial hierarchy by allowing for ethnoracially differentiated opportunities, rewards, and contexts for action at the neighborhood level. To the degree that ethnoracial groups are exposed to fundamentally different local contexts, inequalities in violence (and a host of other outcomes) result. Thus, the intricate interconnections among race, place, and community conditions found in the United States are critical to understanding the sources of race-ethnic differentials in neighborhood violent crime.

Our empirical findings are highly consistent with this perspective. Drawing on data from the NNCS, we showed that whites and non-whites live in separate residential spaces. The isolation is particularly pronounced for blacks for whom nearly forty percent live in places where at least ninety percent of residents are other blacks. The data also demonstrate that these separate residential spaces represent separate social worlds; white local environments are far more stable, socioeconomically advantaged, and imbued with external resources (i.e., residential loans) than black or Latino neighborhoods. Indeed, in urban areas, the distributions of the most central social condition (i.e., disadvantage) are so disparate across ethnoracial groups that levels for white areas barely overlap with those for non-white neighborhoods. Such differences in the characteristics of neighborhoods go a long way in accounting for the vastly different levels of violent crime observed in our data. Notably, gross rates of violence are two and a half to five times greater in the three types of non-white neighborhoods than in white areas (Figure 5), but these differences drop to a maximum of one and three quarters after critical community conditions are taken into account (Table 2).

What are the implications of the racialization perspective we have described, and our striking empirical results, for reducing or eradicating ethnoracial inequality in violent crime patterns? The fundamental answer is in altering the racialized structure that we have pointed to as undergirding the observed racial disparities. However, it is unlikely that such dramatic social change will be brought about in the short run. Thus, alternative solutions that help to alleviate the undue burdens of excessive violence and other serious social problems that some groups confront are needed. Analysts and policymakers could seek approaches to rectify the extraordinary differences in community conditions across neighborhoods of distinct colors. This would involve imbuing non-white areas of cities 
with critical resources to: help alleviate poverty and joblessness; improve educational systems; fix and upgrade the physical infrastructure of housing, businesses, and public facilities; increase homeownership and the value of housing; contribute to family stability; bring jobs and services to areas; and generally increase community well-being. A system of community reparations might be a strategy for building more equitable residential environments between white areas and communities of other colors. This system would distribute dollars, know-how, and programs not to individuals but to neighborhoods that suffer from the long-term historical consequences of a racialized society that harkens back to Jim Crow, slavery, and beyond.

Another approach might be to loosen the links among race, place, and social conditions by "the equalization of opportunities through regional strategies." 90 With a regional strategy, the metropolitan area is treated as an organic whole, relying upon a regional authority to distribute resources and services. ${ }^{91}$ Accordingly, all groups and locations within the metropolitan area are served by the same institutional entities in areas such as housing, zoning, employment, education, public transportation, and policies with respect to businesses. As such, the benefits and pitfalls flowing from these regional authorities would be similar for all metropolitan residents (and organizations). In this way, a regionalism approach should lead to more racially equitable social conditions and, in turn, to lower and more equitable levels of local violence.

While the above suggestions would likely be helpful for non-white areas, their impact in reducing racial disparities in violence (and other undesirable outcomes) would be limited by the persistence of the racialized spatial and social order that is the fundamental basis of the inequality. As noted earlier, the organization of society overall, and the housing market in particular, means that whites have considerable freedom to live and move where they choose. ${ }^{92}$ This privilege of

90. john a. powell, Structural Racism and Spatial Jim Crow, in THE BLACK METROPOLIS IN The Twenty-First Century: RaCe, POWER, AND Politics OF Place, supra note 35, at 54.

91. Id.

92. See generally Kyle Crowder \& Scott J. South, Race, Class, and Changing Patterns of Migration Between Poor and Nonpoor Neighborhoods, 110 AM. J. Soc. 1715 (2005) (discussing how race remains a salient factor in determining the likelihood of exiting or entering poor neighborhoods); Emily Rosenbaum \& Samantha Friedman, Differences in the Locational Attainment of Immigrant and Native-Born Households with Children in New York City, 38 DEMOGRAPHY, Aug. 2001, at 337 (showing that immigrant households with children live in neighborhoods of lower quality); Scott J. South et al., Exiting and Entering High-Poverty Neighborhoods: Latinos, Blacks, and Anglos Compared, 84 SOC. FORCES 873 (2005) (showing that blacks exhibit by far the highest rates of moving into high-poverty neighborhoods); Scott J. South et al., Inter-Neighborhood 
whiteness, coupled with market discrimination and racist attitudes, yields heavily segregated white areas that are distant from the most challenging environments that increase violence. ${ }^{93}$ This isolation and distance is its own reward because whites obtain the substantial benefits of living in neighborhoods and suburban communities that are the safest and most resource rich environments. ${ }^{94}$ When whites are geographically isolated from other groups, they also have little vested interest in addressing the underlying structural problems associated with criminal violence. ${ }^{95}$ Therefore, fundamental and lasting reductions in the unequal distribution of violence will only be achieved by dismantling residential arrangements whereby whites reap undue gains at the expense of neighborhoods of color. This reality poses major concerns regarding community reparations and regional government as strategies for reducing ethnoracial disparities in violence. The former infuses new resources into neglected minority communities, but changes none of the conditions that allow whites to gain substantially by separating themselves from other groups. The regional approach aims to address the consequences of residential arrangements by bringing all parts of the metropolis into single service delivery and regulatory systems.

Migration and Spatial Assimilation in a Multi-Ethnic World: Comparing Latinos, Blacks and Anglos, 87 SOC. FORCES 415 (2008) (discussing the spatial assimilation theory and migration into neighborhoods of varying racial and ethnic composition).

93. See, e.g., Morenoff et al., supra note 72 ("Spatial dynamics coupled with neighborhood inequalities in social and economic capacity are therefore consequential for explaining urban violence.").

94. See, e.g., id. at 552 (noting that increased concentration of affluence "has yielded important consequences for the distribution of homicide").

95. See, e.g., MASSEY \& DENTON, supra note 19, at 158-60 ("[T]he "chocolate city-vanilla suburb' pattern ... gives white politicians a strong interest in limiting the flow of public resources to black-controlled cities."); Lauren J. Krivo et al., Segregation, Racial Structure, and Neighborhood Violent Crime, 114 AM. J. Soc. (forthcoming May 2009). At the same time, there is some evidence that within select areas of even highly segregated cities citizens are able to organize to successfully fight crime, drugs, and other social problems when the neighborhoods are racially and ethnically diverse. For example, evidence shows that in one racially and economically diverse neighborhood in Dayton, Ohio, residents responded to serious local problems through mobilization efforts that encouraged citizen involvement and government investments in ways that stabilized the area and improved local conditions. See Patrick G. Donnelly \& Charles Kimble, Community Organizing, Environmental Change, and Neighborhood Crime, 43 CRIME \& DELINQ. 493, 508 (1997) (discussing mobilization efforts that led to crime reduction); Patrick G. Donnelly \& Theo J. Majka, Residents' Efforts at Neighborhood Stabilization: Facing the Challenges of Inner-City Neighborhoods, 13 SoC. FORUM 189, 209-11 (1998). These efforts were facilitated by a unique city-wide structure for citizen participation that supports groups working together. Similarly, the Dudley Street neighborhood in Boston offers another example of the possibility for cross-group organizing to successfully fight urban deterioration within a context of city-wide segregation. See PETER MEDOFF \& Holly Sklar, Streets of Hope: The FALl AND Rise OF AN URBAN NeIGHBORHOOD 175-79 (1994) (discussing agency collaboration to provide social services). 
However, this leaves in place racial and class segregation, the social processes that maintain such segregation, and various market and other mechanisms by which benefits flow to existing white and other high status areas. Thus, neither of these alternatives would change the fact that white areas would still be far ahead of those for other racial groups in reaping benefits in arenas such as housing value and wealth accumulation, the attraction of favorable institutions, and the formation of informal organizations that support communities.

Race scholars are well aware that policies and programs that attempt to reduce or eliminate racial disparities in violence and many other outcomes that are implemented within the current social organization of society can only yield limited piecemeal change. As such, they call for more systemic social and activist strategies to challenge white privilege and the status quo. ${ }^{96}$ In other words, they argue for a new and militant civil rights movement that demands equality and refuses to accept second-class citizenship for blacks and other people of color. This new social movement also includes a role for social scientists. ${ }^{97}$ In particular, race scholars articulate a need for researchers to demythify and deracialize ideologies (e.g., color-blindness, abstract liberalism), policies, and practices that support systems of racial stratification. ${ }^{98}$. While our work is not a specific response to this call, it provides a concerted attempt to expose the ways in which the underlying racial order perpetuates racial disparities in violence. In so doing, we make clear that progress in eliminating these disparities, as well as others that plague urban areas, will occur only when we attack the broad-based racialized structure of U.S. society.

96. See, e.g., Bonilla-Silva, Racism Without Racists, supra note 2; Bonilla-Silva, White SUPREMACY, supra note 2, at 198-204 (discussing activist strategies to change the "racial status quo"); Tukufu Zuberi \& Eduardo Bonilla-Silva, Telling the Real Tale of the Hunt: Toward a Race Conscious Sociology of Racial Stratification, in WhITE LOGIC, WhITE METHODS: RACISM AND Methodology 329, 335-39 (Tukufu Zuberi \& Eduardo Bonilla-Silva eds., 2008) (arguing for social scientists to "do whatever they can to be active in the various social movements against white supremacy"). See generally Eduardo Bonilla-Silva \& Tukufu Zuberi, Toward a Definition of White Logic and White Methods, in White Logic, White Methods: RACISM AND MeThodology, supra, at 3-27 (discussing how white research methods can reinforce the status quo).

97. See sources cited supra note 95. For further readings regarding assessments of current scientific approaches and recommendations for new approaches to conducting research in racialized fields and building "racial knowledge," see generally RACING RESEARCH, RESEARCHING RACE: Methodological Dilemmas in CRitical Race Studies (France Winddance Twine \& Jonathan W. Warren eds., 2000); White Logic, White Methods: Racism AND Methodology, supra note 96.

98. See sources cited supra notes 95-96. 
APPENDIX A. MEANS OF NEIGHBORHOOD CHARACTERISTICS WITHIN NEIGHBORHOODS OF DIFFERENT COLORS ${ }^{99}$

\begin{tabular}{lllll}
\hline $\begin{array}{l}\text { Neighborhood } \\
\text { Characteristic }\end{array}$ & $\begin{array}{l}\text { White } \\
\text { Areas }\end{array}$ & $\begin{array}{l}\text { Black } \\
\text { Areas }\end{array}$ & $\begin{array}{l}\text { Latino } \\
\text { Areas }\end{array}$ & $\begin{array}{l}\text { Integrated } \\
\text { Areas }\end{array}$ \\
\hline Residential Instability & -.23 & -.21 & .20 & .30 \\
$\quad 36.1$ & 55.2 & 60.8 & 54.4 \\
$\quad$ Percent Renters & 51.6 & 41.4 & 49.8 & 56.3 \\
$\quad$ Percent Movers & 22,073 & 4919 & 6485 & 14,003 \\
Residential Loans & -.41 & -.67 & 1.99 & .31 \\
Immigration & 8.8 & 2.8 & 47.9 & 21.3 \\
$\quad$ Percent Foreign Born & 3.7 & 1.3 & 21.5 & 10.2 \\
$\quad$ Recent Immigrants & 2.4 & 1.3 & 31.6 & 9.4 \\
$\quad$ Linguistically & & & & \\
Isolated & -.67 & 1.03 & .83 & .00 \\
Disadvantage & 23.5 & 47.8 & 47.1 & 32.4 \\
$\quad$ Joblessness & 44.2 & 21.2 & 13.1 & 31.6 \\
$\quad$ Professional & & & & \\
Workers & 39.8 & 9.9 & 6.7 & 24.4 \\
College Graduates & 8.6 & 35.7 & 18.6 & 14.7 \\
Female-Headed & & & & \\
Families & 12.2 & 26.3 & 25.1 & 18.4 \\
Low Wage Jobs & 8.6 & 31.7 & 28.9 & 17.9 \\
Poverty & & & & \\
\hline
\end{tabular}

99. See Table 1 for the definitions of all variables. 